\title{
ANALISIS PEMUNGUTAN, EFEKTIVITAS DAN KONTRIBUSI PAJAK MINERAL BUKAN LOGAM DAN BATUAN TERHADAP PENDAPATAN ASLI DAERAH KOTA TOMOHON
}

\author{
Rivo Reynard Rambitan ${ }^{1}$, Inggriani Elim², Sonny Pangerapan ${ }^{3}$ \\ 1,2,3 Jurusan Akuntansi, Fakultas Ekonomi dan Bisnis, Universitas Sam Ratulangi, Jl. Kampus Bahu, Manado, \\ 95115, Indonesia \\ E-mail : rambitanr@yahoo.com
}

\begin{abstract}
Non-metallic mineral and rock tax is one of the original source of income in Tomohon. This research was conducted to find out how the analysis of pollution from Non Metallic Mineral and Rock Tax and how big the effectiveness and contribution of Mineral Non-Metals and Rocks Tax on the Original Income of Tomohon City. The method of analysis used in this research is descriptive method. The result showed that procedures and procedures for collecting non -metallic minerals and rock taxes in Tomohon City are based on Local Regulation (Perda) No. 43 of 2012 and the effectiveness of Non-Metallic Mineral and Stone Taxes in Tomohon Municipality in 2014 is quite effective, by 2015 effective, 2016 is ineffectiveand in 2017 less effective with an average of 54,97\%. While the Non-Metallic Mineral and Non-Metallic Mineral Revenue Contribution to the Tomohon Distric's Revenue in 2014 to 2017 is very less with an average of 0,94\%.
\end{abstract}

Keywords: Mineral Tax, Collection, Effectiveness, Contribution, Local Original Income

\section{PENDAHULUAN}

Indonesia merupakan negara yang berkembang dimana salah satu elemen pemasukan kas negara terbesar untuk menjalankan roda perekonomian adalah pajak. Pajak saat ini merupakan sumber utama dari suatu negara yang digunakan oleh pemerintah untuk membiayai pengeluaran rutin terlebih untuk membiayai pembangunan baik yang digunakan di pusat sampai ke pelosok daerah dalam bentuk infrastruktur guna tercapai kemakmuran dan kesejahteraan masyarakat. Namun dalam pelaksanaannya terdapat perbedaan kepentingan antara wajib pajak dan pemerintah. Dimana wajib pajak berusaha untuk membayar pajak sekecil mungkin karena dengan membayar pajak berarti mengurangi kemampuan ekonomis masyarakat. Berdasarkan Undang-Undang Nomor 28 Tahun 2009 tentang Pajak Daerah dan Retribusi Daerah, Pajak daerah terbagi menjadi dua yaitu Pajak Provinsi dan Pajak Kabupaten/Kota. Penetapan ini dilakukan berdasarkan dengan kewenangan pengenaan dan pemungutan masing-masing jenis pajak daerah pada wilayah administrasi provinsi atau kabupaten/kota. Salah satu pajak daerah adalah Pajak Mineral Bukan Logam dan Batuan. Sebagai salah satu jenis pajak daerah, Pajak Mineral Bukan Logam dan Batuan mempunyai potensi yang tinggi sebagai pemasukan atau sumber anggaran pendapatan belanja daerah (APBD). Selama ini dapat dilihat hampir semua orang tidak suka membayar pajak karena mereka menganggap bahwa pajak akan mengurangi kekayaan yang mereka miliki. Padahal kesadaran wajib pajak dalam membayar pajak sangat berpengaruh terhadap besarnya pendapatan asli daerah yang pada akhirnya akan digunakan untuk membiayai pembangunan daerah dan menyelenggarakan pemerintahan. Potensi Mineral Bukan Logam dan Batuan adalah kekuatan yang ada di suatu daerah untuk menghasilkan penerimaan Pajak Mineral Bukan Logam dan Batuan serta merupakan pendapatan yang sangat baik bagi daerah apabila kontribusi dari Pajak Mineral Bukan Logam dan Batuan berjalan sesuai dengan diharapkan. Dengan berlakunya Undang-Undang Nomor 28 Tahun 2009 Tentang Pajak Daerah dan 
Retribusi Daerah, maka seluruh penerimaan dari Pajak Mineral Bukan Logam dan Batuan adalah hak daerah karena kegiatan proses pendataan, penilaian, pengadministrasian, pemungutan/penagihan dan pelayanan diselenggarakan sepenuhnya oleh pemerintah daerah. Selain itu untuk melihat kembali pemungutan Pajak Mineral Bukan Logam dan Batuan apakah sudah berjalan sesuai dengan diharapkan. Pengambilan judul ini karena melihat masalah dalam pemungutan Pajak Mineral Bukan Logam dan Batuan yang berada di Kota Tomohon yang meskipun banyak potensi Mineral Bukan Logam dan Batuan akan tetapi penerimaan pajaknya kurang maksimal karena masih banyak yang tak ingin dan tak taat dalam membayar pajak padahal pajak itu sendiri merupakan salah satu sumber Pendapatan Asli Daerah. Oleh karena itu adanya rumusan masalah diantaranya apakah prosedur dan tata cara pemungutan Pajak Mineral Bukan Logam dan Batuan di Kota Tomohon telah dilakukan sesuai dengan peraturan yang ada serta bagaimana efektivitas dan kontribusi dari Pajak Mineral Bukan Logam dan Batuan terhadap Pendapatan Asli Daerah selama tahun 2014-2017 di Kota Tomohon.

\section{TINJAUAN PUSTAKA \\ 2.1 Konsep Akuntansi \\ 2.1.1 Akuntansi}

Diana dan Lilis (2017:1) menyatakan akuntansi adalah sebuah proses untuk menghasilkan informasi bagi para pengguna yang biasanya dalam bentuk laporan keuangan. Pontoh (2013:2) menyatakan akuntansi pada dasarnya menghasilkan informasi dari sebuah sistem akuntansi yang ada di dalam sebuah entitas atau organisasi bisnis yang disebut dengan informasi akuntansi yang akan dimanfaatkan oleh pengguna seperti masyarakat umum, masyarakat intelektual (termasuk didalamnya mahasiswa atau peneliti) dan para pengambil keputusan bisnis dalam organisasi selanjutnya.

\subsubsection{Akuntansi Pajak}

Pelaksanaan perhitungan besarnya jumlah perpajakan berpedoman pada peraturan dan perundang-undangan perpajakan beserta aturan, perhitungan jumlah pajak memiliki hubungan dengan akuntansi.

\subsection{Konsep Pajak}

\subsubsection{Pajak}

Pajak dalam teori Rochmat yang dikutip dari Mardiasmo (2016:33) menyatakan bahwa pajak merupakan iuran rakyat kepada kas negara berdasarkan undang-undang yang dapat dipaksakan dengan tiada mendapat jasa timbal (kontraprestasi) yang secara langsung ditujukan dan digunakan untuk membayar pengeluaran umum.

\subsection{Teori Pemungutan Pajak}

Teori-teori pemungutan pajak antara lain, sebagai berikut:

\section{Teori Asuransi}

Negara melindungi keselamatan jiwa, harta benda, dan hak-hak rakyatnya. Dengan demikian masyarakat wajib membayar pajak yang diberatkan sebagai suatu asuransi karena memperoleh jaminan perlindungan tersebut.

\section{Teori Kepentingan}

Pembagian beban pajak kepada rakyat didasarkan pada kepentingan (misalnya perlindungan) masing-masing orang. Besar pajak yang harus dibayar tergantung dari seberapa besar kepentingan seseorang terhadap negara.

\section{Teori Daya Pikul}

Beban pajak harus dibayar sesuai dengan daya pikul masing-masing orang. Ada 2 pendekatan untuk mengukur daya pikul yaitu:

a.Unsur objektif, yaitu unsur dengan melihat tingginya penghasilan atau kekayaan yang dimiliki seseorang. 
b. Unsur subjektif, yaitu unsur dengan memperhatikan tingginya kebutuhan materil yang harus dipenuhi.

4. Teori Bakti

Dimana dasar dari pemungutan pajak dalam hal ini keadilan terletak pada hubungan rakyat dengan negaranya sebagai warga negara yang berbakti, rakyat harus selalu menyadari bahwa pembayaran pajak adalah sebagai suatu kewajiban.

5. Teori Asas Daya Beli

Acuan keadilan terletak pada akibat pemungutan pajak dalam artian yaitu memungut pajak berarti menarik daya beli dari rumah tangga masyarkat untuk rumah tangga negara, dengan demikian negara akan menyalurkannya kembali ke rakyat lebih diutamakan dalam bentuk pemeliharaan kesejahteraan dan kepentingan masyarakat.

\subsection{Konsep Pajak Daerah}

Dalam Pasal 1 Undang-Undang Nomor 28 Tahun 2009 tentang Pajak Daerah dan Retribusi Daerah : "Kontribusi wajib kepada daerah yang terutang oleh pihak pribadi atau badan yang mempunyai sifat memaksa sebagaimana yang diatur dalam undang-undang, dengan tidak mendapatkan imbalan secara langsung dan digunakan untuk keperluan Daerah bagi sebesar-besarnya kemakmuran rakyat yang merupakan pajak daerah yang selanjutnya disebut pajak".

\subsection{Pajak Mineral Bukan Logam dan Batuan}

Samudra (2015:247) Pajak Mineral Bukan Logam dan Batuan adalah pajak atas kegiatan pengambilan bahan mineral bukan logam dan batuan sesuai dengan peraturan perundang-undangan yang berlaku.

\subsection{Efektivitas}

Pencapaian untuk kerja yang maksimal, yaitu pencapaian target yang berkaitan dengan kualitas, kuantitas dan waktu dimana makin besar presentase target yang dicapai, maka makin tinggi efektivitasnya merupakan dimensi dari produktivitas (hasil). Efektivitas Pajak Mineral Bukan Logam dan Batuan adalah nilai yang dihitung berdasarkan perbandingan realisasi penerimaan Pajak Mineral Bukan Logam dan Batuan dengan target Pajak Minereal Bukan Logam dan Batuan. Adapun cara untuk mengukur efektivitas penerimaan Pajak Mineral Bukan Logam dan Batuan adalah sebagai berikut:

Realisasi Penerimaan (Pajak Mineral

Bukan Logam dan Batuan)

Efektivitas $=$

Target Penerimaan (Pajak Mineral

Bukan Logam dan Batuan)

\subsection{Kontribusi}

Kontribusi adalah sesuatu yang diberikan bersama-sama dengan pihak lain untuk tujuan biaya atau kerugian tertentu atau bersama, sehingga kontribusi yang dimaksud dapat diartikan sebagai sumbangan yang diberikan oleh penerimaan Pajak Bahan Galian Mineral Bukan Logam dan Batuan. Kontribusi dalam Pajak Bahan Galian Mineral Bukan Logam dan Batuan adalah suatu nilai untuk mengetahui tingkat kontribusi yang dihitung berdasarkan persantase perbandingan realisasi penerimaan Pajak Bahan Galian Mineral Bukan Logam dan Batuan dengan realisasi Pendapatan Asli Daerah (PAD). Untuk menghitung kontribusi maka menggunakan rumus sebagai berikut: 


\section{Realisasi Penerimaan (Pajak Mineral \\ Bukan Logam dan Batuan)}

Kontribusi $=$

Realisasi Pendapatan Asli Daerah

\subsection{Pendapatan Asli Daerah}

Pendapatan Asli Daerah (PAD) adalah semua hak daerah yang diakui sebagai penambah nilai kekayaan bersih dalam periode anggaran tertentu.

\subsection{Penelitian terdahulu}

Penelitian terdahulu yang penulis jadikan sebagai bahan pertimbangan dalam melakukan penelitian di Badan Keuangan Daerah Kota Tomohon, yakni penelitian yang dilakukan oleh Melisa dan Lidia (2015), tentang Analisis Efektivitas Pemungutan Pajak Mineral Bukan Logam dan Batuan Berdasarkan Sistem Ketetapan Pajak Serta Kontribusinya Terhadap PAD Kota Bitung, menyatakan bahwa penerimaan Pajak Mineral Bukan Logam dan Batuan dinilai sangat efektif, bahkan melebihi dari target yang ditetapkan. Penerimaan dalam kurun waktu empat tahun dari tahun 2011-2014 tidak terus mengalami peningkatan melainkan berubah-ubah namun tetap diatas target yang ditetapkan.

\section{METODE PENELITIAN}

\subsection{Jenis Penelitian}

Jenis penelitian yang digunakan adalah penelitian deskriptif. Dalam penelitian deskriptif, peneliti mencoba menentukan sifat situasi sebagaimana adanya pada waktu penelitian dilakukan (Dantes, 2012:51). Penelitian ini menganalisis Pemungutan, Efektivitas dan Kontribusi Pajak Mineral Bukan Logam dan Batuan Terhadap Pendapatan Asli Daerah Kota Tomohon.

\subsection{Waktu dan Tempat Penelitian}

Penelitian ini dilakukan di Badan Keuangan Daerah (Dinas Pendapatan, Pengelolaan Keuangan dan Barang Milik Daerah) Kota Tomohon. Periode waktu penelitian dimulai pada bulan Maret-April 2018.

\subsection{Prosedur Penelitian}

Melakukan survei awal, disposisi Pimpinan, menetapkan waktu penelitian, menyiapkan alat bantu penelitian, pengumpulan data, mendapatkan informasi, menganalisis dan mengolah data serta hasil penelitian (kesimpulan dan saran).

\subsection{Metode Pengumpulan Data}

\subsubsection{Jenis Data}

Sujarweni (2014:8-9) Data dalam penelitian merupakan sekumpulan informasi yang diperoleh dari lapangan dan digunakan untuk bahan penelititan meliputi data sebagai berikut. Jenis data dapat dibedakan menjadi 2 jenis,yaitu data kualitatif dan data kuantitatif. Dalam penelitian ini, penulis menggunakan data kualitatif sebagai dasar untuk menganalisis Pemungutan, Efektivitas dan Kontribusi Pajak Mineral Bukan Logam dan Batuan Terhadap Pendapatan Asli Daerah Kota Tomohon.

\subsection{Metode Analisis}

Metode analisis yang digunakan untuk membahas permasalahan dalam penelitian ini adalah metode analisis deskriptif kualitatif, yaitu dengan cara menggambarkan kenyataan atau keadaan atas suatu objek dalam bentuk uraian kalimat berdasarkan keteranganketerangan dari pihak-pihak yang berhubungan langsung dengan penelitian ini. 


\subsubsection{Analisis Efektivitas}

Tabel 3.1 Klasifikasi Pengukuran Efektivitas

\begin{tabular}{|c|c|}
\hline Persentase & Kriteria \\
\hline$>100 \%$ & Sangat Efektif \\
\hline $90-100 \%$ & Efektif \\
\hline $80-90 \%$ & Cukup Efektif \\
\hline $60-80 \%$ & Kurang Efektif \\
\hline$<60 \%$ & Tidak Efektif \\
\hline
\end{tabular}

Dari tabel klasifikasi pengukuran efektivitas diatas menunjukkan bahwa dikatakan sangat efektif apabila $>100 \%$, efektif 90>100\%, 80-90\% cukup efektif, 60-80\% kurang efektif dan $<60 \%$ tidak efektif.

\subsubsection{Analisis Kontribusi}

Tabel 3.2 Klasifikasi Kriteria Kontribusi

\begin{tabular}{|c|c|}
\hline Persentase & Kriteria \\
\hline $0,00 \%-10 \%$ & Sangat Kurang \\
\hline $10,10 \%-20 \%$ & Kurang \\
\hline $20,10 \%-30 \%$ & Sedang \\
\hline $30,10 \%-40 \%$ & Cukup Baik \\
\hline $40,10 \%-50 \%$ & Baik \\
\hline Diatas $50 \%$ & Sangat Baik \\
\hline
\end{tabular}

Sumber : Depdagri, Kepmendagri (Rima Adelina, 2012)

Tabel 3.2 diatas menunjukkan klasifikasi kriteria kontribusi dimana persentase $0,00-10 \%$ masuk dalam kriteria sangat kurang, 10,10-20\% adalah kurang, 20,10-30\% adalah sedang, $30,10-40 \%$ adalah cukup baik, $40,10-50 \%$ adalah baik dan diatas $50 \%$ adalah sangat baik.

\section{HASIL PENELITIAN DAN PEMBAHASAN}

\subsection{Hasil Penelitian}

\subsubsection{Pemungutan Pajak Mineral Bukan Logam dan Batuan di Kota Tomohon}

Objek penelitian dalam penelitian ini adalah Pajak Mineral Bukan Logam dan Batuan yang merupakan pajak yang dikelola oleh Badan Keuangan Daerah (Dinas Pendapatan, Pengelolaan Keuangan dan Barang Milik Daerah) Kota Tomohon. Pajak Mineral Bukan Logam dan Batuan dahulu dipungut dan diadministrasikan oleh pemerintah pusat, tetapi hasilnya dibagikan lagi kepada masing-masing daerah untuk pembangunan daerah dalam bentuk dana bagi hasil pajak. Seluruh penerimaan dari Pajak Mineral Bukan Logam dan Batuan sudah menjadi hak daerah karena kegiatan proses pendataan, penilaian, penetapan, pengadministrasian, pemungutan/penagihan dan pelayanan Pajak Mineral Bukan Logam dan Batuan diselenggarakan sepenuhnya oleh pemerintah daerah ketika sudah berlakunya Undang-Undang Nomor 28 Tahun 2009 Tentang Pajak Daerah dan Retribusi Daerah Dengan berlakunya Undang-Undang Nomor 28 Tahun 2009 Tentang Pajak Daerah dan Retribusi Daerah.

\subsubsection{Target dan Realisasi Pajak Mineral Bukan Logam dan Batuan Kota Tomohon}

Berdasarkan tabel 4.1 di bawah ini menunjukkan bahwa target penerimaan Pajak Mineral Bukan Logam dan Batuan Kota Tomohon tahun $2014 \quad$ Rp450.000.000,00 dan realisasi Rp394.464.662,00. Pada tahun 2015 target Rp395.000.000,00 dan realisasi Rp128.296.775,00. Tahun 2016 target Rp295.000.000,00 dan realisasi Rp108.312.912. Di tahun 2017 target $\mathrm{Rp} 210.000 .000,00$ dan realisasi Rp132.381.472,00. 
Tabel 4.1 Target dan Realisasi Pajak Mineral Bukan Logam dan Batuan Kota Tomohon Tahun 2014-2017

\begin{tabular}{|c|c|c|}
\hline Tahun & Target (Rp) & Realisasi (Rp) \\
\hline 2014 & $450.000 .000,00$ & $394.464 .662,00$ \\
\hline 2015 & $395.000 .000,00$ & $128.296 .775,00$ \\
\hline 2016 & $295.000 .000,00$ & $108.312 .912,00$ \\
\hline 2017 & $210.000 .000,00$ & $132.381 .472,00$ \\
\hline
\end{tabular}

Sumber : Data Badan Keuangan Daerah (Dinas Pendapatan, Pengelolaan Keuangan dan Barang Milik Daerah) Kota Tomohon

\subsubsection{Kontribusi Pajak Mineral Bukan Logam dan Batuan Terhadap Pendapatan Asli Daerah Kota Tomohon}

Berdasarkan tabel 4.2 di bawah ini menunjukkan kontribusi dari Pajak Mineral Bukan Logam dan Batuan terhadap Pendapatan Asli Daerah Kota Tomohon tahun 2014-2017. Pada tahun 2014 realisasi Pajak Mineral Bukan Logam dan Batuan Rp394.464.662,00 sedangkan realisasi dari Pendapatan Asli Daerah sebesar Rp17.378.569.341,00. Tahun 2015 realisasi Pajak Mineral Bukan Logam dan Batuan Rp128.296.775,00 dan realisasi Pendapatan Asli Daerah Rp20.688.883.680,00. Tahun 2016 realisasi Pajak Mineral Bukan Logam dan Batuan Rp108.312.912,00 dan realisasi Pendapatan Asli Daerah Rp26.321.670.690,00. Dibandingkan dengan tahun 2017 realisasi dari Pajak Mineral Bukan Logam dan Batuan sebesar Rp132.381.472,00 dan realisasi dari Pendapatan Asli Daerah sebesar Rp29.543.783.344,00.

Tabel 4.2 Kontribusi Pajak Mineral Bukan Logam dan Batuan terhadap Pendapatan Asli Daerah Kota Tomohon Tahun 2014-2017

\begin{tabular}{|c|c|c|}
\hline Tahun & $\begin{array}{c}\text { Realisasi Pajak } \\
\text { MBLB }(\mathbf{R p})\end{array}$ & $\begin{array}{c}\text { Realisasi PAD } \\
(\mathbf{R p})\end{array}$ \\
\hline 2014 & $394.464 .662,00$ & $17.378 .569 .341,00$ \\
\hline 2015 & $128.296 .775,00$ & $20.688 .883 .680,00$ \\
\hline 2016 & $108.312 .912,00$ & $26.321 .670 .690,00$ \\
\hline 2017 & $132.381 .472,00$ & $29.543 .783 .344,00$ \\
\hline
\end{tabular}

Sumber : Data Badan Keuangan Daerah (Dinas Pendapatan, Pengelolaan Keuangan dan Barang Milik Daerah) Kota Tomohon

\subsection{Pembahasan}

\subsubsection{Prosedur dan Tata Cara Pemungutan Pajak Mineral Bukan Logam dan Batuan di Kota Tomohon}

Berdasarkan penelitian yang dilakukan, maka dapat diketahui bahwa prosedur dan tata cara pemungutan dari Pajak Mineral Bukan Logam dan Batuan di Kota Tomohon ini dilakukan berdasarkan Peraturan Daerah (Perda) Kota Tomohon Nomor 43 Tahun 2012 tentang Sistem Prosedur dan Sanksi Pemungutan Pajak Daerah Kota Tomohon Pasal 14 dan 15 mengenai Pajak Mineral Bukan Logam dan Batuan. Ditetapkan bahwa:

1.Pajak Mineral Bukan Logam dan Batuan disetorkan ke kas daerah baik melalui bank yang ditunjuk dan/atau melalui bendahara penerimaan DPPKAD setiap awal bulan setelah berakhirnya bulan masa pajak, dan/atau paling lambat tanggal 7 setelah berakhirnya bulan masa pajak, misalnya : masa pajak bulan Januari 2011, jatuh tempo pajak terutang adalah tanggal 7 Februari 2011.

2.Setelah batas waktu jatuh tempo sebagaimana dimaksud pada ayat (1) jumlah pajak yang terutang belum dibayarkan/disetorkan maka diberikan surat peringatan I (pertama) dan/atau surat teguran I (pertama) kepada wajib pajak Mineral Bukan Logam dan Batuan sekaligus dinyatakan telah menunggak pajak Mineral Bukan Logam dan Batuan dengan denda 2\% (dua persen), Keterangan: Menunggak 1 (satu) hari dihitung 1 (satu) bulan. 
3.Satu minggu setelah diberikan surat peringatan I (pertama) dan/atau surat teguran I (pertama) sebagaimana dimaksud pada ayat (2) wajib pajak tidak membayar/menyetorkan pajak terutang ditambah denda $2 \%$, maka kembali diberikan surat peringatan II (kedua) dan atau surat teguran II (kedua) kepada wajib pajak Mineral Bukan Logam dan Batuan.

4.Satu minggu setelah diberikan surat peringatan II dan/atau surat teguran II sebagaimana dimaksud pada ayat (3) wajib pajak tidak membayar/menyetorkan pajak terutang ditambah denda 2\%, maka aparat satuan Polisi Pamong Praja memberikan peringatan terakhir kepada wajib pajak Mineral Bukan Logam dan Batuan.

5.Satu minggu setelah diberikan peringatan sebagaimana dimaksud pada ayat (4), ternyata wajib pajak tetap belum atau tidak membayar/menyetorkan pajak terutang ditambah denda $2 \%$, maka aparat satuan Polisi Pamong Praja melakukan penutupan sementara kegiatan/usaha Mineral Bukan Logam dan Batuan tersebut.

6.Penghentian sementara kegiatan/usaha Mineral Bukan Logam dan Batuan sebagaimana dimaksud pada ayat (5) akan dicabut apabila wajib pajak telah membayar/menyetorkan pajak terutang ditambah denda.

7.Satu minggu setelah penghentian sementara sebagaimana dimaksud pada ayat (5) dan ayat (6), ternyata wajib pajak tetap tidak membayar/menyetorkan pajak terutang ditambah denda, masalah tersebut diserahkan kepada aparat hukum untuk diproses sesuai dengan peraturan perundang-undangan yang berlaku.

Tata cara pemungutan Pajak Mineral Bukan Logam dan Batuan dilaksanakan:

a.Melalui laporan produksi (mengisi formulir SPTPD) oleh pemegang Izin Usaha Pertambangan (IUP)/Izin Pertambangan Rakyat (IPR).

b.Melalui kontraktor atau pengurusan Izin Mendirikan Bangunan (IMB) selaku wajib pungut (WAPU).

c.Melalui pengadaan pos di mulut tambang.

\subsubsection{Efektivitas Pajak Mineral Bukan Logam dan Batuan Kota Tomohon Tahun 2014-2017}

Tabel 4.3 di bawah ini menunjukkan efektivitas dari Pajak Mineral Bukan Logam dan Batuan di Kota Tomohon selama tahun 2014-2017.

Tabel 4.3 Efektivitas Penerimaan Pajak Mineral Bukan Logam dan Batuan Kota Tomohon Tahun 2014-2017

\begin{tabular}{|c|c|c|c|c|}
\hline Tahun & $\begin{array}{c}\text { Target } \\
(\mathbf{R p})\end{array}$ & $\begin{array}{c}\text { Realisasi } \\
\text { (Rp) }\end{array}$ & $\begin{array}{c}\text { Persentase } \\
(\%)\end{array}$ & Kriteria \\
\hline 2014 & $450.000 .000,00$ & $394.464 .662,00$ & $87,66 \%$ & Cukup Efektif \\
\hline 2015 & $395.000 .000,00$ & $128.296 .775,00$ & $32,48 \%$ & Tidak Efektif \\
\hline 2016 & $295.000 .000,00$ & $108.312 .912,00$ & $36,72 \%$ & Tidak Efektif \\
\hline 2017 & $210.000 .000,00$ & $132.381 .472,00$ & $63,04 \%$ & Kurang Efektif \\
\hline \multicolumn{3}{|c|}{ Rata-rata } & $54,97 \%$ & Tidak Efektif \\
\hline
\end{tabular}

Sumber : Data Badan Keuangan Daerah (Dinas Pendapatan, Pengelolaan Keuangan dan Barang Milik Daerah) Kota Tomohon

Berdasarkan tabel 4.3 tingkat efektivitas Pajak Mineral Bukan Logam dan Batuan yang paling tinggi tingkat efektivitasnya yaitu pada tahun 2014 dengan persentase 87,66\%. Dibandingkan dengan 3 tahun selanjutnya yaitu pada tahun 2015, 2016 dan 2017 yang mengalami penurunan, dimana pada tahun 2015 tingkat efektivitas hanya pada persentase 32,48\%. Tahun 2016 persentase efektivitas sebesar 36,72\% dan untuk tahun 2017 persentase efektivitas dari Pajak Mineral Bukan Logam dan Batuan sebesar 63,04\%. Jika berdasarkan pada kriteria atau klasifikasi pengukuran efektifitas maka penilaian Pajak Mineral Bukan Logam dan Batuan pada tahun 2014 adalah Cukup Efektif, tahun 2015 Tidak Efektif, tahun 
2016 Tidak Efektif dan untuk tahun 2017 adalah Kurang Efektif. Jadi melihat data yang ada maka jumlah rata-rata dari penerimaan Pajak Mineral Bukan Logam dan Batuan di Kota Tomohon selama tahun 2014-2017 adalah sebesar 54,97\% yaitu Tidak Efektif.

Hal ini menunjukkan bahwa Pemerintah Kota Tomohon masih kurang efektif dalam mengelola Pajak Mineral Bukan Logam dan Batuan serta kurangnya kesadaran dari wajib pajak untuk membayar pajak. Pemerintah Kota Tomohon juga harus melakukan pendataan kepada objek pajak dan subjek pajak dengan turun langsung lapangan/lokasi dan Pemerintah yang ada juga harus mampu memperbaiki pelaksanaan pemungutan Pajak Mineral Bukan Logam dan Batuan khususnya dalam pelayanan pembayaran dan pengelolaannya serta dapat mempertanggungjawabkan penerimaan Pajak Mineral Bukan Logam dan Batuan secara keseluruhan. Dengan hal ini maka wajib pajak bahkan masyarakat juga dapat menyadari bahwa pentingya membayar pajak sehingga pada tahun selanjutnya penerimaan dan pendapatan Pajak Mineral Bukan Logam dan Batuan semakin efektif.

\subsubsection{Kontribusi Pajak Mineral Bukan Logam dan Batuan Terhadap Pendapatatan Asli Daerah Kota Tomohon Tahun 2014-2017}

Berdasarkan tabel 4.4 di bawah ini maka dapat dilihat bahwa kontribusi Pajak Mineral Bukan Logam dan Batuan terhadap Pendapatan Asli Daerah Kota Tomohon rata-rata dari tahun 2014-2017 adalah sebesar 0,94\%. Jika berdasarkan kriteria atau klasifikasi maka kontribusi dari Pajak Mineral Bukan Logam dan Batuan terhadap Pendapatan Asli Daerah Kota Tomohon tahun 2014-2017 penilaiannya adalah Sangat Kurang.

Tabel 4.4 Kontribusi Pajak Mineral Bukan Logam dan Batuan terhadap Pendapatan Asli Daerah Kota Tomohon Tahun 2014-2017

\begin{tabular}{|c|c|c|c|c|}
\hline Tahun & $\begin{array}{c}\text { Realisasi Pajak } \\
\text { MBLB (Rp) }\end{array}$ & $\begin{array}{l}\text { Realisasi PAD } \\
\text { (Rp) }\end{array}$ & $\begin{array}{c}\text { Persentase } \\
(\%)\end{array}$ & Kriteria \\
\hline 2014 & $394.464 .662,00$ & $17.378 .569 .341,00$ & $2,27 \%$ & Sangat Kurang \\
\hline 2015 & $128.296 .775,00$ & $20.688 .883 .680,00$ & $0,62 \%$ & Sangat Kurang \\
\hline 2016 & $108.312 .912,00$ & $26.321 .670 .690,00$ & $0,41 \%$ & Sangat Kurang \\
\hline 2017 & $132.381 .472,00$ & $29.543 .783 .344,00$ & $0,45 \%$ & Sangat Kurang \\
\hline \multicolumn{3}{|c|}{ Rata-rata } & $0,94 \%$ & Sangat Kurang \\
\hline
\end{tabular}

Sumber : Data Badan Keuangan Daerah (Dinas Pendapatan, Pengelolaan Keuangan dan Barang Milik Daerah) Kota Tomohon

Dapat dilihat dari tabel 4.4 bahwa kontribusi Pajak Mineral Bukan Logam dan Batuan terhadap Pendapatan Asli Daerah Kota Tomohon pada tahun 2014-2017 semakin menurun kontribusinya. Dimana kontribusi Pajak Mineral Bukan Logam dan Batuan terhadap Pendapatan Asli Daerah Kota Tomohon pada tahun 2014 hanya sebesar Rp394.464.662,00 atau hanya pada persentase 2,27\% (Sangat Kurang). Tahun 2015 Rp128.296.775,00 atau pada persentase 0,62\% (Sangat Kurang), Tahun 2016 Rp108.312.912,00 atau persentase 0,41\% (Sangat Kurang), dan pada tahun 2017 Rp132.381.472,00 atau hanya pada persentase 0,45\% dan masih dalam klasifikasi (Sangat Kurang). Hal ini menunjukkan bahwa kontribusi Pajak Mineral Bukan Logam dan Batuan di Kota Tomohon masih sangat kurang, maka perlu adanya peran dari Pemerintah Kota Tomohon untuk lebih mengoptimalkan pemungutan terhadap Pajak Mineral Bukan Logam dan Batuan sehingga dapat memberikan kontribusi yang lebih meningkat di tahun selanjutnya. Selain itu banyaknya data yang tidak akurat dan tidak sesuai dengan kondisi di lapangan yang sebenarnya dan masih banyak pula yang belum memiliki bahkan tidak suka mengurus ijin usaha sehingga penerimaan kurang optimal dan kurangnya kesadaran dari wajib pajak dalam membayar Pajak Mineral Bukan Logam dan 
Batuan, hal ini juga menjadi faktor penghambat untuk meningkatkan penerimaan Pajak Mineral Bukan Logam dan Batuan.

Dengan adanya kerjasama dengan pihak-pihak yang terkait dalam pelaksanaan pemungutan dan pengelolaan Pajak Mineral Bukan Logam dan Batuan diharapkan mampu mengoptimalkan kontribusi Pajak Mineral Bukan Logam dan Batuan terhadap Pendapatan Asli Daerah Kota Tomohon.

\section{KESIMPULAN DAN SARAN}

\subsection{Kesimpulan}

Hasil dari penelitian dan pembahasan sebelumnya, maka dapat ditarik kesimpulan sebagai berikut:

1.Prosedur dan tata cara pemungutan Pajak Mineral Bukan Logam dan Batuan di Kota Tomohon dilakukan berdasarkan Peraturan Daerah (Perda) Nomor 43 Tahun 2012 tentang Sistem Prosedur dan Sanksi Pemungutan Pajak Daerah Kota Tomohon Pasal 14 dan 15 mengenai Pajak Mineral Bukan Logam dan Batuan, tetapi untuk sanksi pemungutan pajak daerah belum dilakukan sesuai dengan peraturan yang ada.

2.Efektivitas Pajak Mineral Bukan Logam dan Batuan di Kota Tomohon selama tahun 20142017 dari hasil penelitian yang dilakukan dapat dikatakan sangat memperihatinkan sehingga perlu adanya peran penting dari Pemerintah yang ada dan bagi wajib pajak. Dimana pada tahun 2014 hanya pada persentase 87,66\% (Cukup Efektif), tahun 2015 dengan persentase 32,48\% (Tidak Efektif), tahun 2016 dengan persentase 36,72\% (Tidak Efektif) dan untuk tahun 2017 dengan persentase 63,04\% (Kurang Efektif) dengan rata-rata 54,97\%.

3.Kontribusi dalam penerimaan Pajak Mineral Bukan Logam dan Batuan terhadap Pendapatan Asli Daerah Kota Tomohon tahun 2014-2017 dengan rata-rata hanya sebesar 0,94\%. Jika berdasarkan kriteria atau klasifikasi maka kontribusi dari Pajak Mineral Bukan Logam dan Batuan terhadap Pendapatan Asli Daerah Kota Tomohon penilaiannya adalah sangat kurang bahkan sangat memperihatinkan. Dengan artian bahwa Pemerintah Kota Tomohon kurang optimal dalam pengelolaan Pajak Mineral Bukan Logam dan Batuan sebagai sumber pendapatan daerah serta kurangnya kesadaran dari wajib pajak untuk membayar pajak dan masih banyak wajib pajak yang belum dan tidak mau mengurus ijin usaha Mineral Bukan Logam dan Batuan yang mereka miliki.

\subsection{Saran}

Berdasarkan hasil penelitian dan pembahasan serta kesimpulan tersebut, maka penulis memberikan saran antara lain:

1.Sebaiknya Pemerintah Kota Tomohon melakukan penyuluhan yang lebih intensif dan secara berkala kepada wajib pajak dan masyarakat tentang pentingnya membayar pajak khususnya Pajak Mineral Bukan Logam dan Batuan karena secara tidak langsung realisasi dari pajak akan sangat bermanfaat bagi masyarakat nantinya serta menjelaskan kepada mereka bahwa dana yang dipungut itu digunakan untuk membantu kepentingan daerah dengan meningkatkan pembangunan secara umum, dengan begitu masyarakat menjadi termotivasi untuk membayar pajak sehingga efektivitas dan kontribusi Pajak Mineral Bukan Logam dan Batuan terhadap Pendapatan Asli Daerah Kota Tomohon lebih meningkat.

2.Pemerintah Kota Tomohon juga harus lebih aktif untuk melakukan informasi kepada wajib pajak tentang batas akhir pembayaran Pajak Mineral Bukan Logam dan Batuan dan batas jatuh tempo pajak terutang.

3.Pemerintah Kota Tomohon harus memberikan sanksi tegas kepada wajib pajak yang tidak memenuhi kewajiban perpajakan sebagaimana mestinya.

4.Pemerintah Kota Tomohon diharapkan menyediakan petugas keamanan di setiap lokasi atau tempat pengambilan Mineral Bukan Logam dan Batuan yang ada untuk melakukan pencatatan pengambilan Mineral Bukan Logam dan Batuan, dengan begitu dapat mengetahui 
seberapa banyak kendaraan yang keluar masuk dalam lokasi atau tempat pengambilan tersebut serta menghitung dan dapat mengetahui seberapa banyak material dari Mineral Bukan Logam dan Batuan yang diambil setiap harinya. Dengan begitu maka Pemerintah mempunyai pencatatan sendiri dan penyetoran pajaknya sesuai dengan hasil yang di ambil oleh wajib pajak.

5.Pemerintah Kota Tomohon diharapkan mampu menjelaskan kepada wajib pajak yang belum memiliki ijin usaha Pajak Mineral Bukan Logam dan Batuan tentang betapa pentingnya memiliki ijin usaha dan alangkah baiknya Pemerintah yang ada mempermudah setiap sistem dari kepengurusan ijin usaha Pajak Mineral Bukan Logam dan Batuan sehingga tidak terlalu merepotkan bagi wajib pajak untuk mengurus ijin usaha tersebut.

\section{DAFTAR PUSTAKA}

Ilyas, B. W., dan Burton, R. 2013. Hukum Pajak: Teori, Analisis dan perkembangannya. Salemba Empat. Jakarta.

Ismail, S. 2014. Analisis Perhitungan Penyetoran dan Pelaporan Pajak Penghasilan Pasal 25 Pada CV. Delta Dharma. Jurnal EMBA, No. 2, Vol. 2. ISSN 2303-1174. Hal. 1491-1499.

Mardiasmo. 2016. Perpajakan. Edisi Revisi. Andi. Yogyakarta.

Nyoman, Dantes. 2012. Metode Penelitian. Andi. Jakarta.

Pontoh, Winston. 2013. Akuntansi Konsep dan Aplikasi. Jakarta.

Sujarweni, Wiratna. 2014. Metodologi Penelitian Lengkap, Praktis dan Mudah Dipahami. Pustaka Baru Pers. Yogyakarta.

Sujarweni, Wiratna. 2015. Metodologi Penelitian-Bisnis \& Ekonomi. Pustaka Baru Press. Yogyakarta.

Undang-Undang Republik Indonesia Nomor 28 Tahun 2009. Pajak Daerah dan Retribusi Daerah. Lembaran Negara Republik Indonesia Tahun 2009. Jakarta.

Undang-Undang Republik Indonesia Nomor 16 Tahun 2009. Ketentuan Umum dan Tata Cara Perpajakan. Lembaran Negara Republik Indonesia Tahun 2009. Jakarta.

Wangka, F. Melisa., dan Mawikere, Lidia. 2015. Analisis Efektivitas Pemungutan Pajak

Mineral Bukan Logam dan Batuan Berdasarkan Sistem Ketetapan Pajak Serta Kontribusinya Terhadap PAD Kota Bitung. Jurnal Hasil Riset Manajemen Universitas Sam Ratulangi Manado. 